\title{
THE SANDBOX INVESTMENT
}





\title{
THE SANDBOX INVESTMENT
}

\author{
The Preschool Movement \\ and Kids-First Politics
}

\author{
David L. Kirp
}

Harvard University Press

Cambridge, Massachusetts

London, England 


\section{Copyright (C) 2007 by David L. Kirp All rights reserved \\ Printed in the United States of America}

First Harvard University Press paperback edition, 2009.

\section{Library of Congress Cataloging-in-Publication Data}

$$
\text { Kirp, David L. }
$$

The sandbox investment : the preschool movement and kids-first politics / David L. Kirp.

$$
\text { p. } \mathrm{cm} \text {. }
$$

Includes bibliographical references and index. ISBN 978-0-674-02641-4 (cloth : alk. paper)

ISBN 978-0-674-03235-4 (pbk.)

1. Education, Preschool-Political aspects-United States.

2. Education, Preschool-United States-Philosophy. I. Title.

$$
\text { LB1140.23.K57 } 2007
$$

$372.210973-\mathrm{dc} 22 \quad 2007009624$ 
To Ed Zigler

Public servant, scholar, mentor, and mensch 
